\title{
Application of Landsat-7 satellite data and a DEM for the quantification of thermokarst-affected terrain types in the periglacial Lena-Anabar coastal lowland
}

\author{
Guido Grosse, Lutz Schirrmeister \\ \& Timothy J. Malthus
}

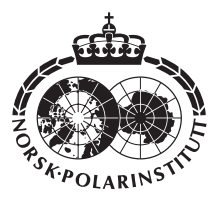

\begin{abstract}
Extensive parts of Arctic permafrost-dominated lowlands were affected by large-scale permafrost degradation, mainly through Holocene thermokarst activity. The effect of thermokarst is nowadays observed in most periglacial lowlands of the Arctic. Since permafrost degradation is a consequence as well as a significant factor of global climate change, it is necessary to develop efficient methods for the quantification of its past and current magnitude. We developed a procedure for the quantification of periglacial lowland terrain types with a focus on degradation features and applied it to the Cape Mamontov Klyk area in the western Laptev Sea region. Our terrain classification approach was based on a combination of geospatial datasets, including a supervised maximum likelihood classification applied to Landsat-7 ETM+ data and digital elevation data. Thirteen final terrain surface classes were extracted and subsequently characterized in terms of relevance to thermokarst and degradation of ice-rich deposits. $78 \%$ of the investigated area was estimated to be affected by permafrost degradation. The overall classification accuracy was $79 \%$. Thermokarst did not develop evenly on the coastal plain, as indicated by the increasingly dense coverage of thermokarst-related areas from south to north. This regionally focused procedure can be extended to other areas to provide the highly detailed periglacial terrain mapping capabilities currently lacking in global-scale permafrost datasets.
\end{abstract}

G. Grosse \& L. Schirrmeister, Alfred Wegener Institute for Polar and Marine Research, Research Unit Potsdam, Telegrafenberg A45, 14473 Potsdam, Germany, ggrosse@awi-potsdam.de; T. J. Malthus, Institute of Geography, School of GeoSciences, University of Edinburgh, Drummond St., Edinburgh EH8 9XP, UK.

Underlying about $24 \%$ of the land surface of the Northern Hemisphere (Zhang et al. 1999), permafrost is an ideal indicator of environmental changes, as its stability depends on a set of environmental and climatic factors. Many processes in the Arctic permafrost regions have effects of global relevance, such as the carbon cycle of tundra wetlands (Semiletov et al. 1996; Smith et al. 2004). It is widely accepted that the Arctic environment will react earlier and to a greater extent than the global average response under currently estimated climate change scenarios (ACIA 2004). Thus, an understanding of Arctic permafrost regions has become an increasingly important objective.

The application of remote sensing data for the monitoring of these largely remote and extensive landscapes is often the most cost-effective tool, and is therefore a fast growing research area. By using remote sensing, it is possible to observe such environments frequently and at large scales, 
observe change, and deliver basic data for the Arctic and global change discussion.

One of the most striking and important processes in global change is the past and modern degradation of permafrost. Studies of this topic are of significant value for various environmental modelling tasks dealing with global and regional parameters like permafrost distribution, periglacial landscape dynamics, coastal dynamics, and matter and energy fluxes. The value of remote sensing in permafrost research has already been demonstrated (Pollard \& French 1980; Morrissey et al. 1986; Lewkowicz \& Duguay 1999; Ermolin et al. 2002), but only a few approaches discuss permafrost degradation and related landscapes (Sellmann 1975; Jorgenson et al. 2001; Hinkel et al. 2003; Grosse et al. 2005; Lantuit \& Pollard 2005). Despite these previous research efforts and the good quality of available remote sensing data, the quantification of permafrost degradation is still a challenge to be met for the pan-Arctic periglacial regions. Some suitable methods, based on automated analyses of remote sensing data in combination with digital elevation models (DEM), have been proposed for landscape analysis in non-Arctic regions (e.g. Florinsky 1998; Walsh et al. 1998; MacMillan et al. 2003; Wulder et al. 2004).

Until now, investigations of permafrost and periglacial processes based on remote sensing, DEM and thematic geospatial data have been conducted mainly in alpine permafrost settings (e.g. Etzelmüller et al. 2001; Bartsch et al. 2002; Gude et al. 2002). The extensive Arctic lowland regions have rarely been treated with quantitative analyses of periglacial geomorphology and processes, such as the degradation of ice-rich permafrost by thermokarst, at an appropriate high resolution landscape scale.

Thermokarst is defined as the thawing of icerich permafrost or melting of massive ice, and the subsequent surface subsidence and formation of characteristic landforms (van Everdingen 1998). In fact, thermo-erosive and thermo-abrasive processes are also controlled by thermokarst (French 1996). Many studies of thermokarst have been published since the early 1950s about various regions of Canada (e.g. Mackay 1963; French 1974), Alaska (e.g. Hopkins 1949; Black 1969; Osterkamp \& Romanovsky 1999) and Russia (e.g. Romanovskii 1961; Czudek \& Demek 1970; Soloviev 1973; Romanovskii et al. 2000). Global descriptions of thermokarst and its environmen- tal implications are given by Washburn (1979) and French (1996).

Our approach presents an integrated use of optical remote sensing, DEM and GIS-based image stratification for the identification and quantification of different types of periglacial terrain surfaces with a focus on thermokarst-affected terrain in a typical periglacial lowland tundra dominated by ice-rich permafrost. The approach is part of multidisciplinary, joint German-Russian research efforts aimed at the dynamics of permafrost (e.g. Romanovskii et al. 2004), coastal dynamics (e.g. Rachold et al. 2000) and the reconstruction of the Late Quaternary palaeo-environment in the Laptev Sea region (e.g. Schirrmeister et al. 2002), lasting several years. Within these efforts, the investigated area near Cape Mamontov Klyk is the first site situated on the western Laptev Sea coast (Fig. 1) and thus forms an interesting location for regional comparison of palaeoenvironmental, geomorphological and geological results with the eastern Laptev Sea sites. Our approach complements ongoing palaeo-environmental studies of permafrost sequences with remote sensing and GIS-based spatial studies. Eventually both are combined to yield a palaeogeographic reconstruction and up-scaling of local field data at landscape scales. Remotely sensed information on geomorphology, geology and land cover, as well as the spatial extent and distribution of thermokarst were obtained as important parameters for the reconstruction of the palaeoenvironmental development of these landscapes during the Late Quaternary.

The summarized objectives of our study were: (1) The development of a method for the quantification of permafrost degradation using remote sensing data with high detail and large coverage, DEMs, and GIS-based spatial analysis. (2) The quantification of permafrost degradation in the investigation area to clarify the general significance of thermokarst processes for landscape dynamics and its relevance for future flux studies in the region. (3) The support of regional palaeogeographical reconstructions using our enhanced understanding of the development and activity of thermokarst processes in the region.

\section{Physiographic setting}

The study area covers $3403 \mathrm{~km}^{2}\left(73.33-73.66^{\circ} \mathrm{N}\right.$, $116.0-119.0^{\circ} \mathrm{E}$ ) and is situated in the western 


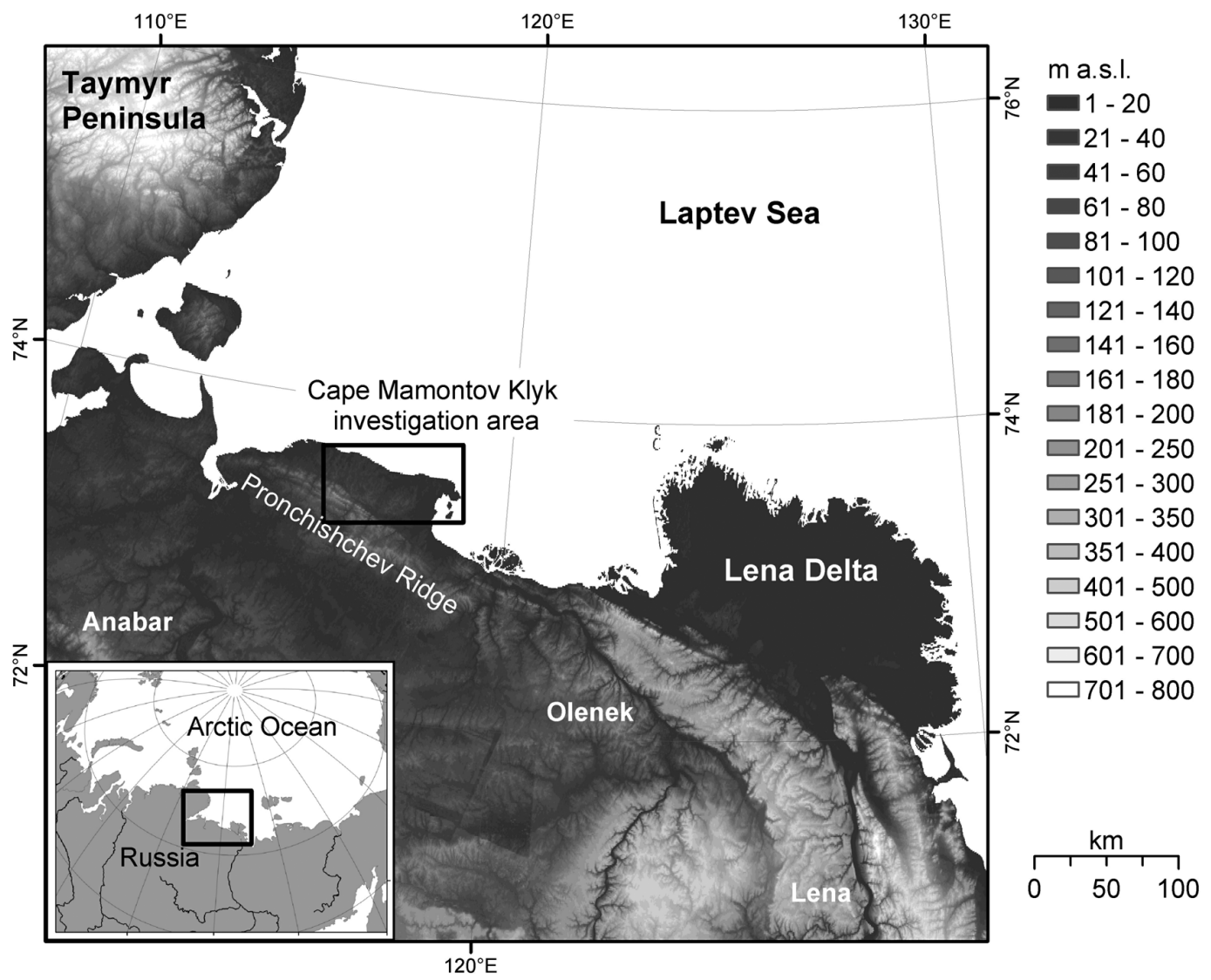

Fig. 1. Location of the investigation area in the western Laptev Sea coastal lowlands, northern Siberia. Map prepared with elevation data from GLOBE Task Team (1999).

Laptev Sea coastal lowland between the rivers Anabar and Olenek, in north-central Siberia (Fig. 1). It is bordered by the Laptev Sea to the north and by the Pronchishchev Ridge about $30 \mathrm{~km}$ to the south. The coastal lowland in front of this hill range is a smoothly sloped plain with elevations between 25 and $55 \mathrm{~m}$ a.s.l. (Fig. 2). Altitudes increase towards the south, to a maximum height of $270 \mathrm{~m}$. The overall inclination of the plain is less than $1^{\circ}$ towards NNE. The study area is part of the Arctic tundra zone (Treshnikov 1985), with long, severe winters and short, cold summers. The mean annual air temperature is $-14^{\circ} \mathrm{C}$. The mean winter temperature is about $-22^{\circ} \mathrm{C}$ and mean summer temperatures vary from +5 to $+10^{\circ} \mathrm{C}$ (Treshnikov 1985). The region receives 230-270 mm of mean annual precipitation, $75 \%$ of which falls in summer. In general, snow cover starts at the end of September and disappears towards the end of June. The snow cover thickness is less than
$50 \mathrm{~cm}$. The study territory belongs to the zone of continuous permafrost reaching $400-600 \mathrm{~m}$ in depth (Yershov 1998). The mean annual ground temperature is -11 to $-12^{\circ} \mathrm{C}$, and the thickness of the active layer varies between $20-50 \mathrm{~cm}$ in July. The permafrost coasts in the area are affected by strong coastal erosion (Are 1999). Major geomorphological features in the plain are river valleys with meandering streams, discharging towards the north, north-east and east (Fig. 3). The longest streams originate in the Pronchishchev Ridge. Deep thermokarst depressions and thermokarst lakes, most of them ellipsoid and strictly northsouth oriented, occur along the river valleys and on elevated surfaces between the river valleys and thermokarst depressions. These elevations, called yedoma, are erosional remnants of the Late Pleistocene accumulation plain consisting of icerich deposits of the Ice Complex formation. The whole plain is incised by thermo-erosional val- 


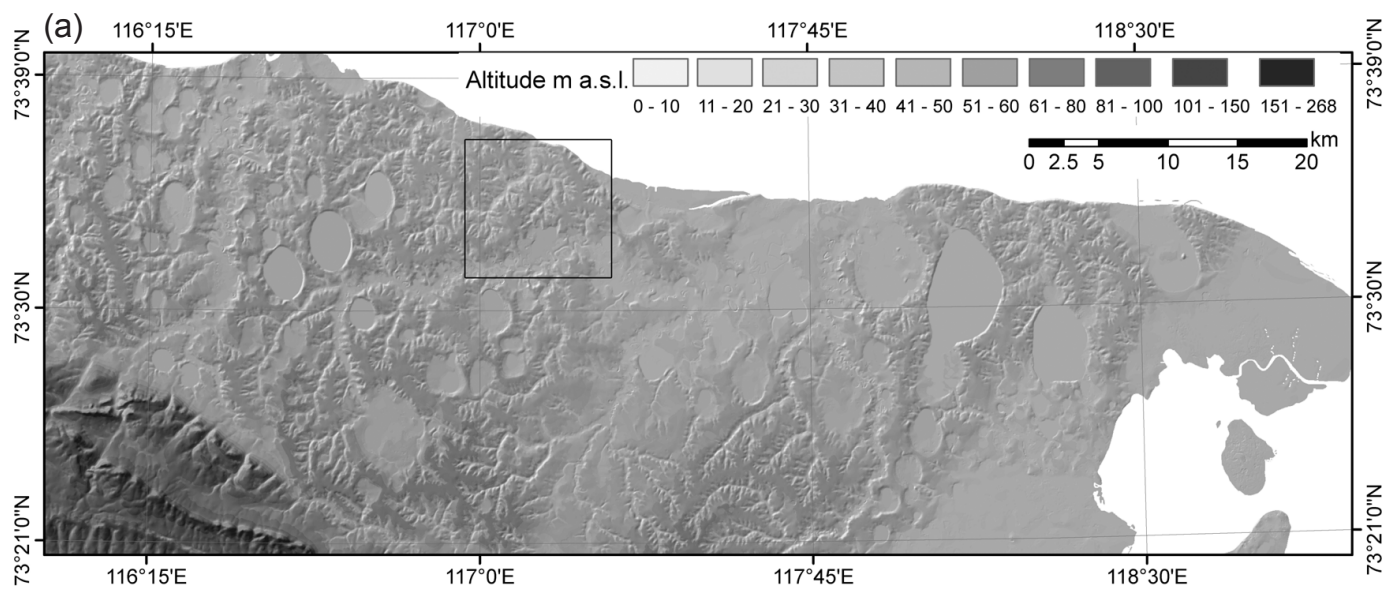

(b)

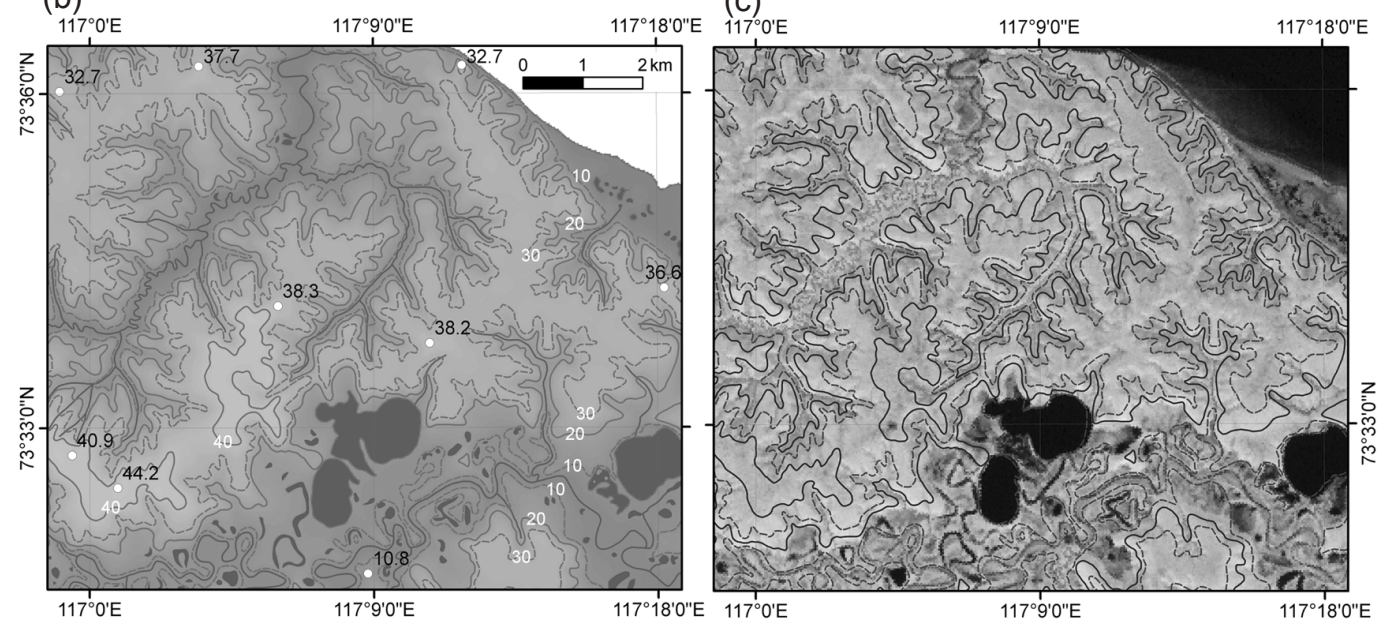

Fig. 2. (a) Digital elevation model of the investigation area, (b) DEM subset with elevation contours showing the typical geomorphology of the region and (c) the same subset with elevation contours and data from Landsat-7 ETM+ band 5, demonstrating the good correlation of the topographical map data for DEM generation with the remotely sensed data.

leys, which drain the uplands towards depressions, river valleys or the coast. A schematic view of major relief features and the local geology of the coastal plain is given in Fig. 4.

The sedimentary deposits of the coastal plain consist of three main units. Lowermost are Middle to Late Pleistocene silts and sands of limnic-alluvial origin. This strata contains ice wedges and has a gravimetric segregated ice content of 25-40 wt\% (compared to dry sediment mass). Thick alternating peat-sand layers occur in the upper part of this unit. The sandy deposits outcrop in deep river valleys and thermokarst depressions. Following are Late Pleistocene to Holocene deposits, which are the most extensive deposits cropping out at the surface in the region. These consist of ice-supersaturated silty to sandy sediments (Ice Complex formation) with a high organic content. The ground ice in these strata consists of large ice wedges and segregated ice. The gravimetric segregated ice content is $50-90 \mathrm{wt} \%$, whereas in zones with ice bands or peat layers the ice content may exceed far above $100 \mathrm{wt} \%$. The average thickness of the Ice Complex is $20-30 \mathrm{~m}$, with a thinning towards the hill range. The Holocene deposits consist of silty to sandy sediments with a high organic content and of various origin (fluvial, limnic, thermokarst and marine deposits). They outcrop in river valleys, thermokarst depressions, thermo-erosional valleys and coastal sites of the region. The gravimetric segregated ice content is up to $130 \mathrm{wt} \%$. 
Fig. 3. Landsat-7 ETM+ image of the investigation area (band combination 5-4-3), showing the location of all 178 field sites, where ground data were collected during the field campaign. The white frames mark the field investigation areas around Cape Mamontov Klyk (A), a thermokarst depression east of it (B) and a thermokarst depression west of it (C). Additional evaluation sites derived from high-resolution Corona images are also indicated. After image stratification only the categories "plain" (D) and "inland water bodies" (E) were used for a maximum likelihood classification. The categories "hill range" $(\mathrm{F})$ and "marine water" $(\mathrm{G})$ were omitted from the classification process.

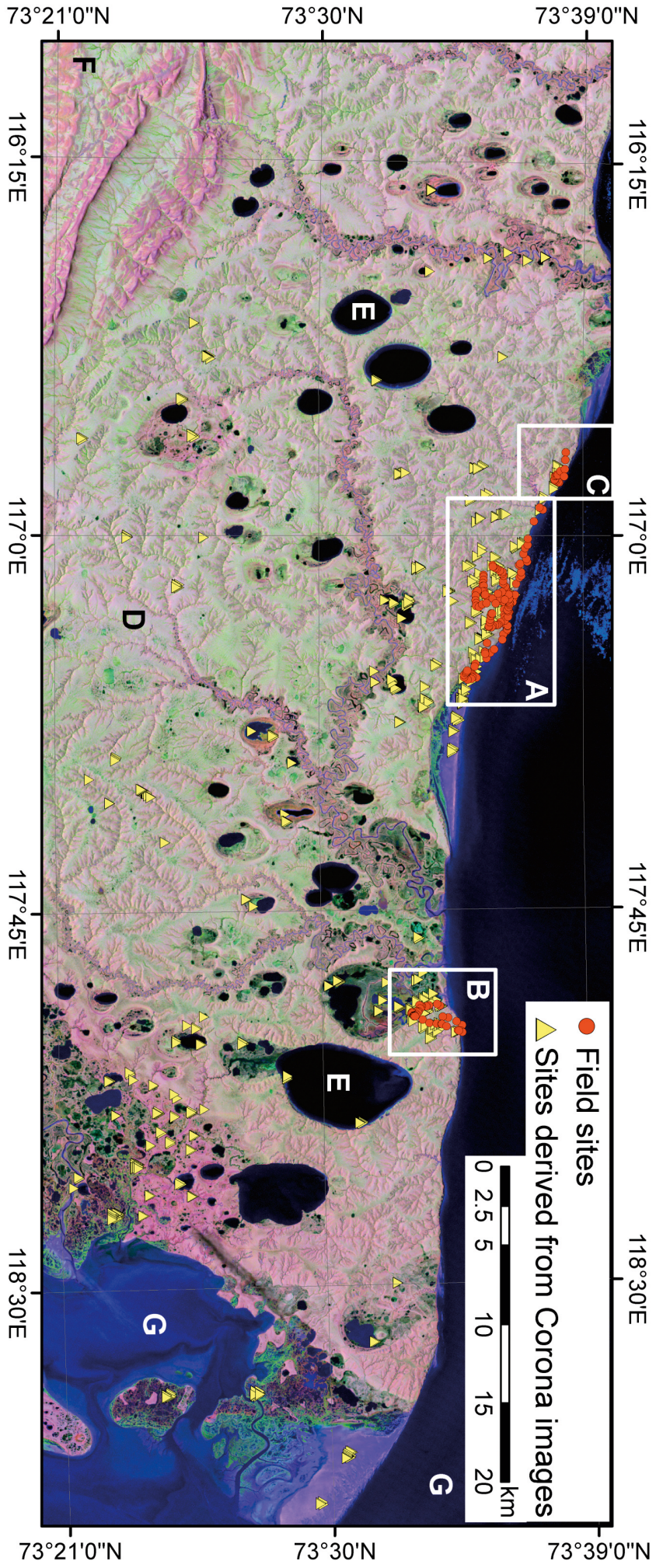




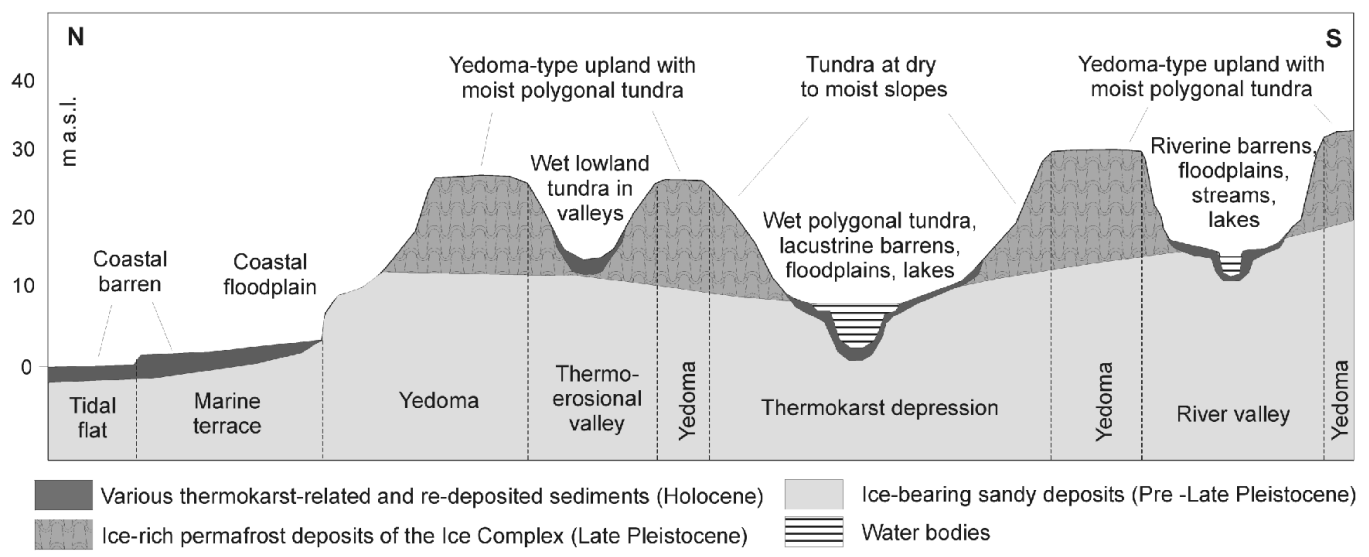

Fig. 4. Schematic view of major relief features identified in the field, classes associated with them and the geological situation in the investigation area at Cape Mamontov Klyk.

AMS radiocarbon datings from these deposits (L. Schirrmeister, unpubl. data) suggest Early to Late Holocene ages and thus are in general agreement with ages from other thermokarst sites in the Laptev Sea region. Additionally, in places the Ice Complex is discordantly covered by less than 2 $\mathrm{m}$ ice-rich sediments that were formed by smallscale initial thermokarst during the Holocene.

The high content of segregation ice and the occurence of large ice wedges in all these deposits result in a high total ice volume and thus a very high subsidence potential for the region.

\section{Database and methods}

\section{Remote sensing data}

The area of investigation was covered by a subset from a multi-spectral Landsat-7 ETM+ satellite image from 4 August 2000 (path 139, row 8; Fig. 3 ). The image was level $1 \mathrm{G}$ systematically corrected, including standard radiometric and geometric corrections. For the image classification only bands $1-5$ and 7 were used. They have $30 \mathrm{~m}$ ground resolution, and cover the visible, near infrared and shortwave infrared wavelengths (e.g. Goward et al. 2001). To convert the raw 8-bit digital numbers to reflectance and to correct for time/location-specific atmospheric conditions, an atmospheric correction was applied based on image values alone using a dark object subtraction approach modified to include a correction for atmospheric transmittance. The approach adopted was that developed by Chavez (1996) and named COST, as the cosine of the solar zenith angle is used as an approximation for atmospheric transmittance. Chavez (1996) shows that there is a first order relation between these two values and the resulting atmospheric correction produces good results for a wide range of conditions. For accuracy estimation we compared spectra of surface types derived from the corrected satellite image with standard spectra provided by a spectral library (in this case, the John Hopkins University spectral library). Although Chavez (1996) states that the COST method has not been tested for solar zenith angles greater than $55^{\circ}$, we successfully applied the method to our data (solar zenith angle of $56.2^{\circ}$ ) and achieved good results. As a final step, the image was more precisely georectified using 73 ground control points derived from topographic maps. The root mean square error for the rectification averaged 0.89 pixels, that is, a horizontal error of less than $30 \mathrm{~m}$ for most locations.

Additionally, three panchromatic $3 \mathrm{~m}$ ground resolution images and one $10 \mathrm{~m}$ ground resolution image from CORONA satellite archives covering large parts of the investigation area were used for subsequent evaluation of the classification results. The images were acquired on 20 July 1965 and 14 July 1975 . These high resolution datasets were used to collect additional ground information and to supplement the field data. Individual geomorphological structures (thermokarst depressions, 
river valleys, pingos) were manually mapped for the whole investigation area with a simple image combination technique of CORONA images and Landsat-7 data, based on the overlay of both image types in the form of semi-transparent GISlayers. Thermo-erosional valleys and yedoma uplands were mapped with the same technique at two sites (Fig. 3, sites A and B).

\section{Digital elevation data}

The DEM of the investigation area was calculated from manually digitized elevation information of three scanned and geo-referenced 1:100000 topographic map sheets (Fig. 2). All the topographical information (contours, elevation points, streams and lakes) was used for the calculation of the DEM using the TOPOGRID tool of ArcInfo ${ }^{\mathrm{TM}}$ (Fig. 2). TOPOGRID is based on an enhanced ANUDEM algorithm after Hutchinson (1989) and calculates a hydrologically correct DEM by using drainage enforcement and removal of spurious sinks. The iterative algorithm produced good results for this type of periglacial landscape, although a small error may be introduced by the removal of natural sinks in some locations. For the output DEM a grid cell size of $30 \mathrm{~m}$ was chosen, for better correlation with the Landsat-7 ETM+ pixel size. The vertical accuracy of the DEM calculation was tested by comparing 304 original elevation points from the map with corresponding DEM grid cells. 286 values $(94.1 \%)$ were within an error range from $-1 \mathrm{~m}$ to $+1 \mathrm{~m}$. The mean error was $+0.1 \mathrm{~m}$, indicating the good performance of the DEM algorithm and the absence of major interpolation residuals. Additionally, lacking correspondence between the map-derived DEM and real small-scale geomorphological features was reduced by supplementary mapping with the high resolution CORONA images. The visual inspection (Fig. 2) and the comparison of the DEM with a tachymetry transect along the coastline near Cape Mamontov Klyk indicated an acceptably good absolute accuracy of the DEM, and thus sufficient quality to be used in the classification and the geomorphological analysis.

\section{Fieldwork}

Fieldwork was conducted in the vicinity of Cape Mamontov Klyk (Fig. 3) during a RussianGerman field campaign in August 2003 (Schirrmeister et al. 2004). Fieldwork included sedi- mentological and cryolithological sampling of outcrops exposed at the up to $30 \mathrm{~m}$ high coastal cliff, a tachymetry transect conducted along the coastline and the investigation of the hinterland for ground data acquisition in terms of surface characteristics and geomorphology.

Altogether, surface parameters were observed and described for 178 sites (Fig. 3). The closer area around Cape Mamontov Klyk contributed 129 sites, and two remote thermokarst depressions contributed another 49 sites. The recorded parameters for each site include relief type, slope inclination, major vegetation composition, estimation of soil moisture, active layer depth and quantity and type of water bodies. A site was successfully included in the study, when the parameters were relatively homogeneous within a radius of about $25 \mathrm{~m}$. Depending on its morphological situation and surface characteristics, each site was assigned to one of seven major terrain surface classes occurring in the plain (Fig. 4). The field data were used to verify the classification results.

\section{Methodological approach}

Thermokarst and thermo-erosion result in negative relief forms like deep depressions or valleys, which are easy to identify in tundra regions because of generally minor vegetation cover. These structures either contain large lakes or have a local hydrological regime resulting in high soil moisture at the bottom. The high soil moisture benefits vegetation communities adapted to very wet conditions. Such vegetation communities are quite distinguishable from communities settling in upland positions or on well-drained slopes. Their spectral properties are also largely different. Thus, the relief and vegetation characteristics of thermokarst structures enable the discrimination from other relief features using both remotely sensed and elevation data. Furthermore, developmental stages of a periglacial landscape can be deduced by the spatial, morphometric and spectral analyses of geomorphological units, as well as relative or absolute age determinations. A similar approach has been applied to thermokarst basins by Hinkel et al (2003) in Alaska. Qualitative conclusions on thermokarst development in a region can be deduced from this approach.

To examine the key site at Cape Mamontov Klyk and the surrounding coastal plain we integrated the Landsat-7 ETM+ data with the DEM, 


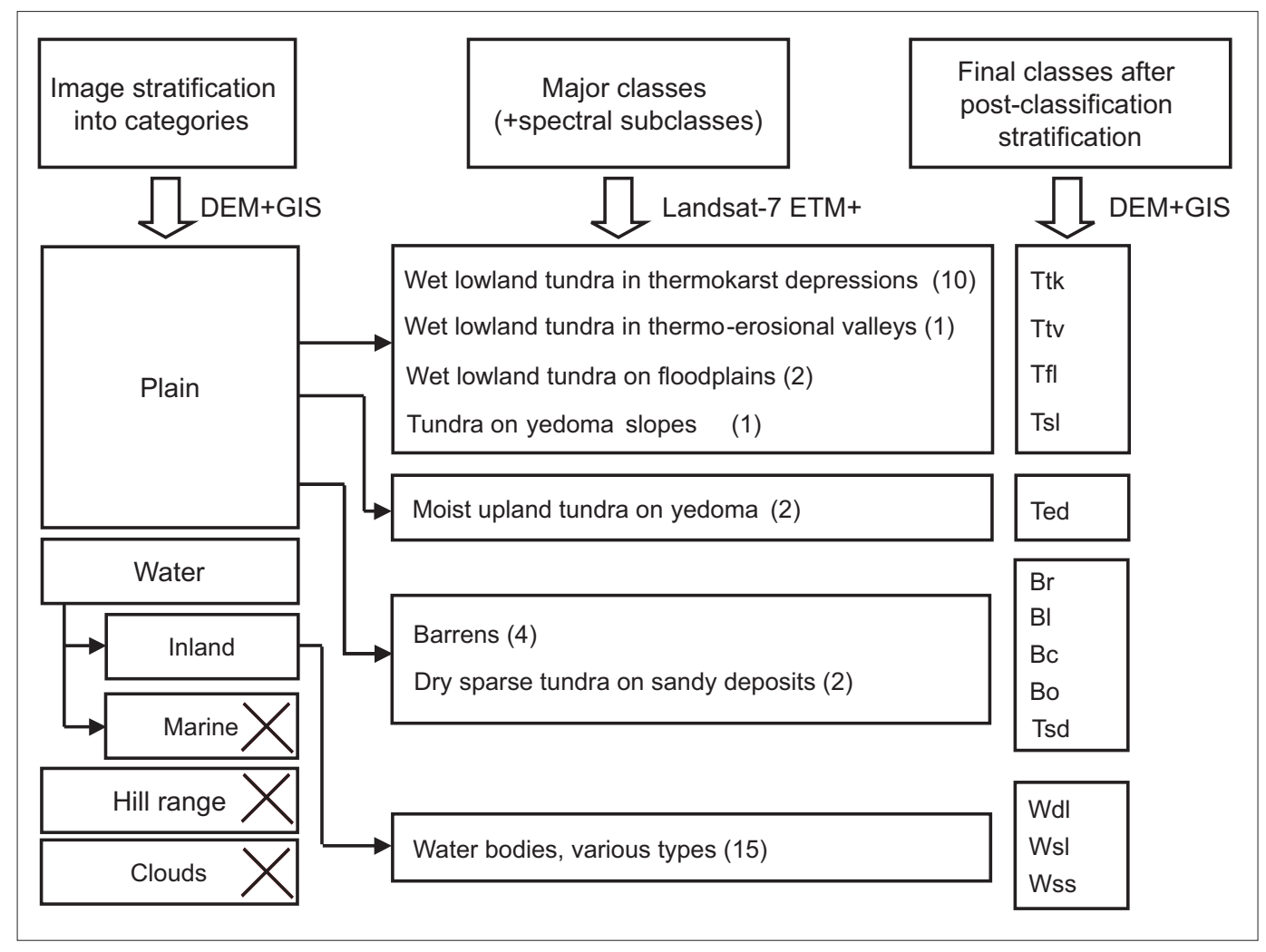

Fig. 5. Image classification scheme.

and subsequently ran a supervised classification on the combined dataset. The aim of the classification was to map terrain surfaces and to quantify thermokarst-affected surfaces in the investigation area.

The classification approach adopted was based on a combination of image stratification and maximum likelihood classification (Fig. 5). Since thermokarst terrain is situated only in the coastal plain, we separated it from other terrain categories. At first, the few cloudy areas $\left(14 \mathrm{~km}^{2}\right)$ in the image were manually masked. Next a decision tree was used to stratify the image into three categories: "water", "plain" and "hill range". We separated water from land using a threshold of $15 \%$ reflectance in the short wave infrared wavelength (band 5). Pixels with lower reflectance were assigned to water. We applied a DEM-derived altitude threshold of $55 \mathrm{~m}$ to separate the remaining non-water pixels into a "hill range" and a "plain" category. The altitude of $55 \mathrm{~m}$ was empirically defined, as outcropping bedrock and rock debris was detected by visual inspection only in pixels higher than $55 \mathrm{~m}$. When pixels with outcropping bedrock or rock debris occurred in the resulting mask polygon, all pixels in this particular polygon were associated with the "hill range" category. Other polygons with elevations above $55 \mathrm{~m}$ but without pixels indicating bed rock or rock debris were reintegrated in the "plain" category. The category "water" was further divided into a marine part (Laptev Sea and bays) and an inland part (thermokarst lakes and rivers) by an image segmentation algorithm. For further classification with the maximum likelihood algorithm only pixels from the category "plain" $\left(2111 \mathrm{~km}^{2}\right)$ and the sub-category "inland water bodies" $\left(206 \mathrm{~km}^{2}\right)$ were used, as only these categories covered the features of interest (Fig. 3).

Training data acquired from visual interpretation of the Landsat-7 ETM+ images were used for the maximum likelihood classification. Data selection was guided by field knowledge and a geological map. The whole set of training data consisted of eight major classes (seven land, one water), divided into 37 spectral subclasses (22 
Final

subclass Description

$\mathrm{Bc} \quad$ Barrens, coastal. Marine terraces with mainly sandy deposits, elevated about $1 \mathrm{~m}$ a.s.l., barren or sparsely vegetated; driftwood accumulations; several $100 \mathrm{~m}$ in width; active layer $>1 \mathrm{~m}$ deep; tidal flats with clayey to sandy deposits, $>100 \mathrm{~m}$ width during low tide

$\mathrm{Br} \quad$ Barrens, riverine. Fluvial terraces with silty-sandy deposits, point bars with spotty vegetation or sandbanks; active layer $>1 \mathrm{~m}$ deep; width of these terraces mostly $>50 \mathrm{~m}$

B1 Barrens, lacustrine. Beaches or barren terraces of some large lakes; mostly in areas where the sandy deposits underlaying the Ice Complex outcrop

Bo Barrens, other types. Includes nival niches, snow patches and barrens in front of them, which were identified mainly in thermo-erosional valleys close to the hill range for this Landsat-7 image; other pixels, which probably indicate patches of non-vegetated sandy deposits, were observed in the southeast of the investigation area

Ttk Wet tundra with indications of thermokarst. Areas with many small ponds and low-centre polygons dominated by wetnessadapted plants, like sedges and mosses; this class occurs mainly on the bottoms of the extensive subsidence areas in thermokarst depressions; Ttk is also detected in other regions closer to the hill range, where so-called "dellies" occur (these are initial thermokarst features indicating subsurface drainage from elevated areas)

Tfl Wet lowland tundra in floodplain-like areas. Riverine, lacustrine and coastal lowlands with very poor drainage, large amount of ponds in low-centre ice-wedge polygons and relatively sparse vegetation (mostly sedges); high ratio of water sufaces compared to land surface

Ttv Wet tundra mainly in thermo-erosional valleys. Wet and flat floors of wide U-shaped thermo-erosional valleys with shallow running water or small ponds; dominated by dense vegetation of grasses, sedges and mosses

Ted Moist to wet tundra on yedoma uplands. Areas with moist and moderate moist upland tundra (grass, moss, lichen); these upland areas represent remnants of the Late Pleistocene accumulation surface; the deposits below consist of synsedimentary frozen, ice-rich sediments

Ts1 Tundra on yedoma slopes. Relatively well-drained slope areas surrounding the yedoma uplands towards depressions or valleys; dominated by tussocky grass tundra and often covered with thermokarst mounds

Tsd Tundra above sandy, relatively well-drained deposits: Occurs mainly in the eastern part of the investigation area, where sandy deposits outcrop at the surface, which in other regions are covered by the Ice Complex, and in large river valleys, where sand was deposited due to fluvial processes

Wdl Water, deep large lakes. Extensive deep thermokarst lakes, often with shallow littoral terraces, and situated in thermokarst depressions; known water depths up to $29 \mathrm{~m}$, diameter of the lakes is up to several $\mathrm{km}$

Wsl Water, shallow large lakes. Extensive lakes with general shallow bathymetry, situated within a depression or river valley; lake area in this class was empirically defined with $>0.15 \mathrm{~km}^{2}$

Wss Water, small shallow lakes, rivers and mixels. Small lakes or lake remnants in lowlands and small ponds on yedoma uplands; lake area in this class was empirically defined with $>0.15 \mathrm{~km}^{2}$. Active and dead river channels, maximal river widths are $60 \mathrm{~m}$, maximal lengths $100 \mathrm{~km}$. Mixels, consisting of vegetated or barren shores of lakes and rivers and overgrown ponds
Interpretation of thermokarst and degradation of the Ice Complex deposits

Ice Complex deposits already completely degraded

Ice Complex deposits already completely degraded

Ice Complex deposits already completely degraded

No common interpretation possible; snow patches accumulate mostly in nival niches of thermoerosional valleys; they are important factors of erosion in the lowland

Ice Complex deposits already partially to completely degraded; existence of taliks possible; refreezing taliks are indicated by the presence of pingos especially in the north-eastern part of the study area

Ice Complex deposits already strongly to completely degraded

Ice Complex deposits already partially to strongly degraded; thermokarst valleys are important factors of hydrology due to drainage of uplands and water supply for thermokarst depressions

Ice Complex deposits largely not degraded; in places occurrence of small ponds with initial thermokarst development and active layer deepening

Ice Complex deposits already weakly to partially degraded

Ice Complex deposits already completely degraded; occurence of small basins or basin remnants indicates thermokarst also in sandy deposits

Ice Complex deposits already completely degraded; existence of deep basins indicates thawing also of underlaying sandy deposits; extent taliks very likely

Ice Complex deposits already partially to completely degraded; existence of taliks possible

On yedoma uplands: Ice Complex deposits or weakly degraded; depending on drainage, high potential for lake-growing, initial thermokarst and permafrost degradation. In lowlands and river valleys: Ice Complex deposits already strongly to completely degraded 
land, 15 water) (Fig. 5).

The spectral separability of the individual training data was evaluated and improved for each category with the n-Dimensional Visualizer ${ }^{\mathrm{TM}}$ tool in the ENVI ${ }^{\mathrm{TM}}$ image processing software. This tool can help rotate a scatterplot with pixel clusters of training classes interactively in $\mathrm{n}$ dimensions. The coordinates of a pixel in the scatterplot are determined by its spectral properties, or by its reflectance values in different wavelengths. For the category "plain" we used the six optical Landsat-7 ETM+ bands, the Normalised Difference Vegetation Index (NDVI) derived from the red and near infrared band, the DEM (scaled to $0-1$ ) and a derived slope map (scaled to $0-1$ ). Hence, the scatterplot had nine dimensions. The pixel clusters of the training classes were compared with respect to how well they were separated from each other in all nine dimensions and how compact the pixel clusters were. Scattered clusters were condensed by omitting obviously outlying pixels. Means and standard deviations from each cluster were enhanced in this way, resulting in an improved classification using the maximum likelihood method. The standard parameters of the Jeffries-Matusita Distance and Transformed Divergence were computed to measure the spectral separability for all classes. Both values are based on the covariance-weighted distance between the class means. They were scaled

Table 2. Spatial extent of each class in the study area. The number in brackets after the water classes indicates the number of individual lakes.

\begin{tabular}{lcc}
\hline Class name & Area $\mathrm{km}^{2}$ & Area \% \\
\hline $\mathrm{Bc}$ & 51.6 & 2.2 \\
$\mathrm{Br}$ & 11.2 & 0.5 \\
$\mathrm{Bl}$ & 3.9 & 0.2 \\
$\mathrm{Bo}$ & 0.5 & 0.0 \\
$\mathrm{Ttk}$ & 260.0 & 11.2 \\
$\mathrm{Tfl}$ & 99.8 & 4.3 \\
$\mathrm{Ttv}$ & 340.0 & 14.7 \\
Ted & 514.8 & 22.2 \\
Tsl & 674.1 & 29.1 \\
Tsd & 155.1 & 6.7 \\
Total land surface & 2111.0 & 91.1 \\
Wdl (121) & 129.0 & 5.6 \\
Wsl (58) & 30.9 & 1.3 \\
Wss (8928) & 46.6 & 2.0 \\
Total water bodies (9107) & 206.5 & 8.9 \\
\hline Total classified area & 2317.5 & 100 \\
\hline
\end{tabular}

between 0 and 2 and indicate how each class is statistically separate from another class. During the iterative evaluation process, classes with separability values less than 1.9 were re-examined in the n-Dimensional Visualizer ${ }^{\mathrm{TM}}$ tool and further refined by condensing the clusters and omitting outlying pixels. Finally, the maximum likelihood classification was applied separately for the category "plain". For the sub-category "inland water bodies" the maximum likelihood classification was conducted in the same manner, but with the 6 Landsat-7 bands only (i.e. omitting the DEM, slope, and NDVI data layers).

For further improvements in classification accuracy, several rule-based algorithms for postclassification stratification were applied for some of the classes within a GIS. The rules were based on altitude and distance to coast, rivers or lakes. The classes "barrens" and "inland water bodies" were thereby refined and further separated. Finally, we obtained 13 classes (Table 1).

\section{Classification results}

The final thematic map derived from the classification indicates that classes related directly to permafrost degradation (see Table 1), like Tsl, Ttk, Ttv and W, cover the majority of the total analysed area of $2317 \mathrm{~km}^{2}$ (Fig. 6). The largest of these classes is Tsl, covering alone $29 \%$ of the region, whereas the class Ted, consisting of tundra with non-degraded permafrost, covers only $22 \%$ (Table 2). If we consider Ted as the only class not affected by permafrost degradation, we observe that $78 \%$ of the investigated area are affected by thermokarst, thermo-erosion or slope denudation (Fig. 6).

For each of the classes the mean elevation above sea level and spectral characteristics were calculated (Fig. 7). The class Ted has the highest mean elevation-about $40 \mathrm{~m}$. The mean elevations of Ttk, Ttv and Tsl are between 20 and $25 \mathrm{~m}$. All other classes have mean elevations lower than $15 \mathrm{~m}$. The barren (B) and water (W) classes are well separated from vegetated classes by their spectral properties. Of the $\mathrm{W}$ classes, Wdl has the lowest reflectance and NDVI values, whereas Wss has a relatively high NDVI, resulting from the presence of mixed water/vegetation pixels along shorelines and overgrown shallow ponds. The classes Ted, Ttk, Ttv and Tsl have rather similar reflectance curves, although Tsl has 
Fig. 6. Final classification map of the investigated area.

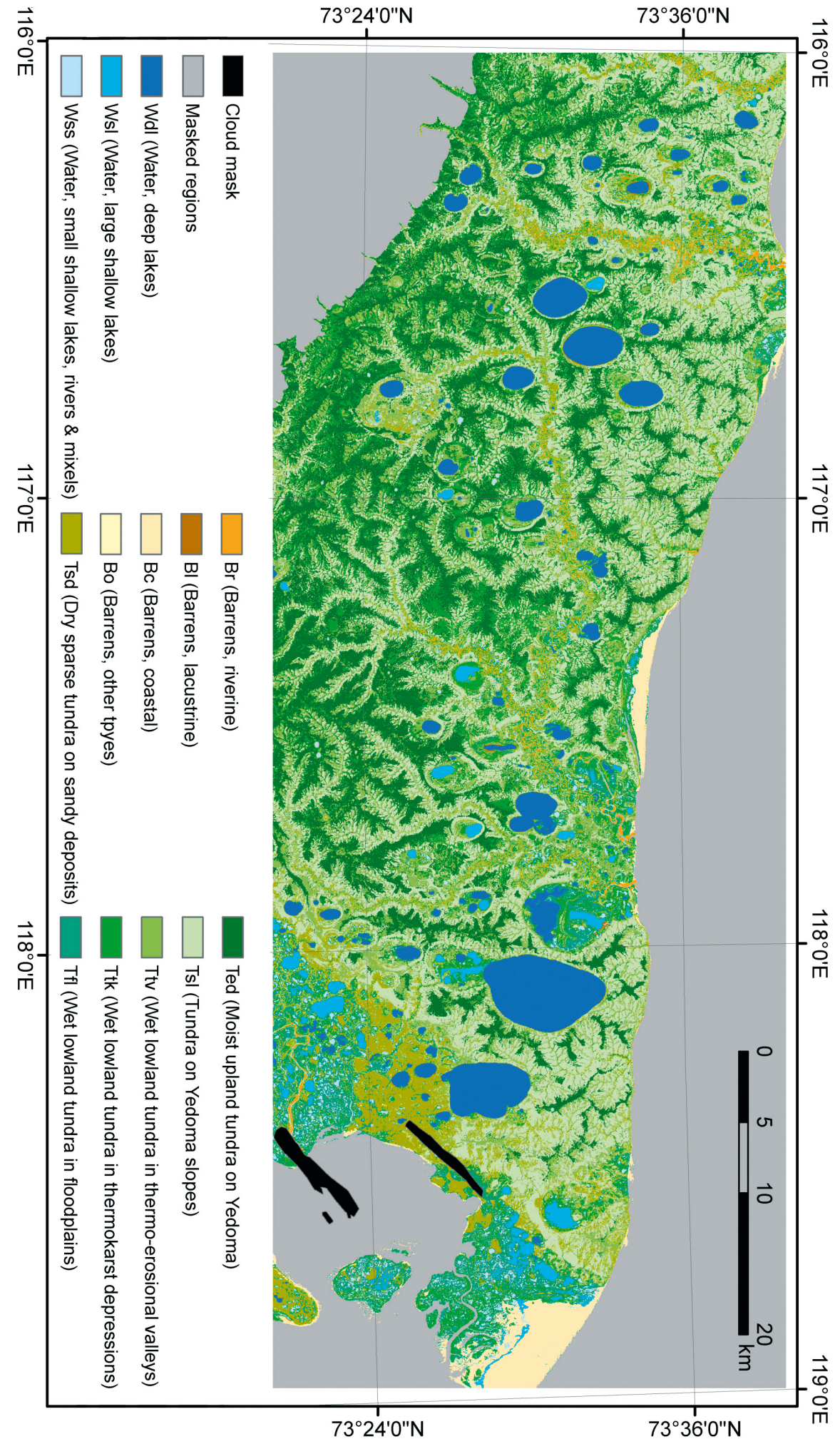


a slightly lower NDVI and the reflectances of Ttk and Ttv are slightly lower, which indicates the higher soil water content in both classes. Tfl has the lowest reflectances and NDVI, as this class is charaterized by many ponds (predominantly lowcentre polygons) and a generally heavily saturated ground. Tsd has a similar low NDVI and a relatively high reflectance in band 5, which is typical for sparser vegetation and a higher soil signal.

For further evaluation of the classification, the class composition of manually mapped typical geomorphological structures was analysed (Table 3). Thermokarst depressions and river valleys were mapped along the upper boundary of their surrounding slopes. Clearly, the main class in thermokarst depressions is $\mathrm{W}$, followed by Tsl and Ttv. representing the slope areas, and Ttk. The class composition of river valleys is heterogeneous and consists of similar proportions of Tsd, Ttv and Tsl, and, to a smaller extent, of Ttk. As most of the rivers are quite narrow, the class W occurs only at $7.5 \%$. Pingos are mainly characterized by Tsl and to a lesser amount by Tsd, both characterizing their relatively dry surface due to upheaval and subsequent good drainage. yedoma uplands are mainly composed of Ted, and to a much lesser extent of Tsl, Ttk and Ttv. The class Ttk also occurs in uplands close to the Pronchishchev Ridge. Within a $30 \mathrm{~m}$ buffer around the central axes of thermo-erosional valleys, the class Ttv dominates, followed by Tsl and other tundra types. Within a $60 \mathrm{~m}$ buffer, the class Tsl dominates over the other classes.

\section{Accuracy assessment and technical discussion}

The accuracy of the classification result was evaluated initially through visual inspection of the Landsat-7 ETM+ image. A second independent dataset was compiled with a stratified random selection using $10 \%$ of each class from a pixel pool, derived from the field data and interpretation of the $10 \mathrm{~m}$ CORONA image. This dataset was used for the calculation of a confusion matrix (Table 4). The four barren classes and three water classes were condensed into classes B and $\mathrm{W}$. The

Table 3. Class composition for some interactively mapped geomorphological structures

\begin{tabular}{|c|c|c|c|c|}
\hline \multirow{2}{*}{$\begin{array}{l}\text { Mapped structures } \\
156 \text { thermokarst depressions, inclusive } \\
\text { surrounding slopes }\end{array}$} & \multicolumn{4}{|c|}{ Four most common classes $(\%)$} \\
\hline & W (34) & Tsl (18.5) & Ttv (16) & Ttk (12) \\
\hline 16 pingos & Tsl (59.5) & Tsd (18) & Ttv (10) & Ttk (4.5) \\
\hline $\begin{array}{l}7 \text { river valleys, inclusive surrounding } \\
\text { slopes }\end{array}$ & Tsd (23.5) & $\operatorname{Ttv}(22)$ & Tsl (20) & Ttk (12.5) \\
\hline $\begin{array}{l}68 \text { thermo-erosional valleys ( } 30 \mathrm{~m} \text { buffer } \\
\text { around the central valley axis) }\end{array}$ & $\operatorname{Ttv}(51)$ & Tsl (35) & Tsd (5.5) & Ttk (5) \\
\hline $\begin{array}{l}68 \text { thermo-erosional valleys ( } 60 \mathrm{~m} \text { buffer } \\
\text { around the central valley axis) }\end{array}$ & Tsl (45.5) & $\operatorname{Ttv}(41.5)$ & Tsd (5) & Ttk (4.5) \\
\hline 12 yedoma uplands & Ted (80) & Tsl (10.5) & Ttk (5.5) & $\operatorname{Ttv}(3.5)$ \\
\hline
\end{tabular}

Table 4. Confusion matrix of classification and ground truth data.

\begin{tabular}{lrrrrrrrrr} 
Class & \multicolumn{1}{c}{ Ground truth (pixel) } \\
& B & Tsd & Tsl & Ttv & Ttk & Tfl & Ted & W & Total \\
\hline B & 95 & 0 & 0 & 0 & 0 & 3 & 0 & 0 & 98 \\
Tsd & 1 & 57 & 0 & 1 & 1 & 0 & 0 & 1 & 61 \\
Tsl & 1 & 1 & 90 & 17 & 12 & 1 & 9 & 0 & 131 \\
Ttv & 0 & 0 & 11 & 44 & 28 & 1 & 1 & 0 & 85 \\
Ttk & 0 & 0 & 3 & 11 & 36 & 8 & 5 & 0 & 63 \\
Tfl & 0 & 0 & 0 & 0 & 5 & 33 & 0 & 0 & 38 \\
Ted & 0 & 0 & 0 & 3 & 4 & 0 & 108 & 0 & 115 \\
W & 0 & 0 & 0 & 0 & 0 & 16 & 0 & 76 & 92 \\
Total & 97 & 58 & 104 & 76 & 86 & 62 & 123 & 77 & 683 \\
\hline
\end{tabular}


overall classification accuracy for our approach with the Landsat-7 ETM+ image was $78.9 \%$. The Kappa value, a measure of agreement with the training data, was 0.76 . Other classification approaches using Landsat images and auxiliary data for vegetation classification in tundra environments reported comparable accuracies in the range of $60-85 \%$ overall accuracy (Joria \& Jorgenson 1996; Virtanen et al. 2004). Reported overall accuracies increase for small investigation areas areas with high density of field work and ground truth data. For instance, Bartsch et al. (2002) classified periglacial geomorphic process units in a $20 \mathrm{~km}^{2}$ alpine catchment area with Landsat-5 TM data and a DEM, achieving $85-93 \%$ overall accuracy.

In our approach the most obvious misclassification was identified for classes Ttk and Ttv, which are genetically and spectrally very similar (Table 4, Fig. 7). These classes cover similar thermodenudation terrain types, often with similar vegetation communities (sedges, grasses and mosses) and soil moisture conditions or presence of subpixel water bodies.

As the classes Ttk and Ttv are similarly interpreted in terms of thermokarst intensity, this misclassification is considered not to be severe. Analyses with 3 m CORONA images showed that areas in uplands classified as Ttk are subsurface drainage features on yedoma slopes. They are considered to be an early form of thermokarst, so-called delly structures. The images also show that the class Ttv on yedoma uplands is characterized by many water-filled low-centre ice wedge polygons especially in regions with poor drainage.

Often, thermokarst-affected tundra landscapes are spatially complex in terms of geomorphology and vegetation cover. One of the most important factors is that geomorphological features, hydrological conditions and vegetation communities can change dramatically even at scales smaller than those of a $30 \mathrm{~m}$ Landsat pixel. This makes the referencing process of the various data layers, including the field data, a crucial step and a prominent source of misclassification.

\section{General discussion}

The detailed classification and mapping of periglacial terrain types in circum-Arctic lowlands will allow the volumetric quantification of thermokarst activity during the Holocene and
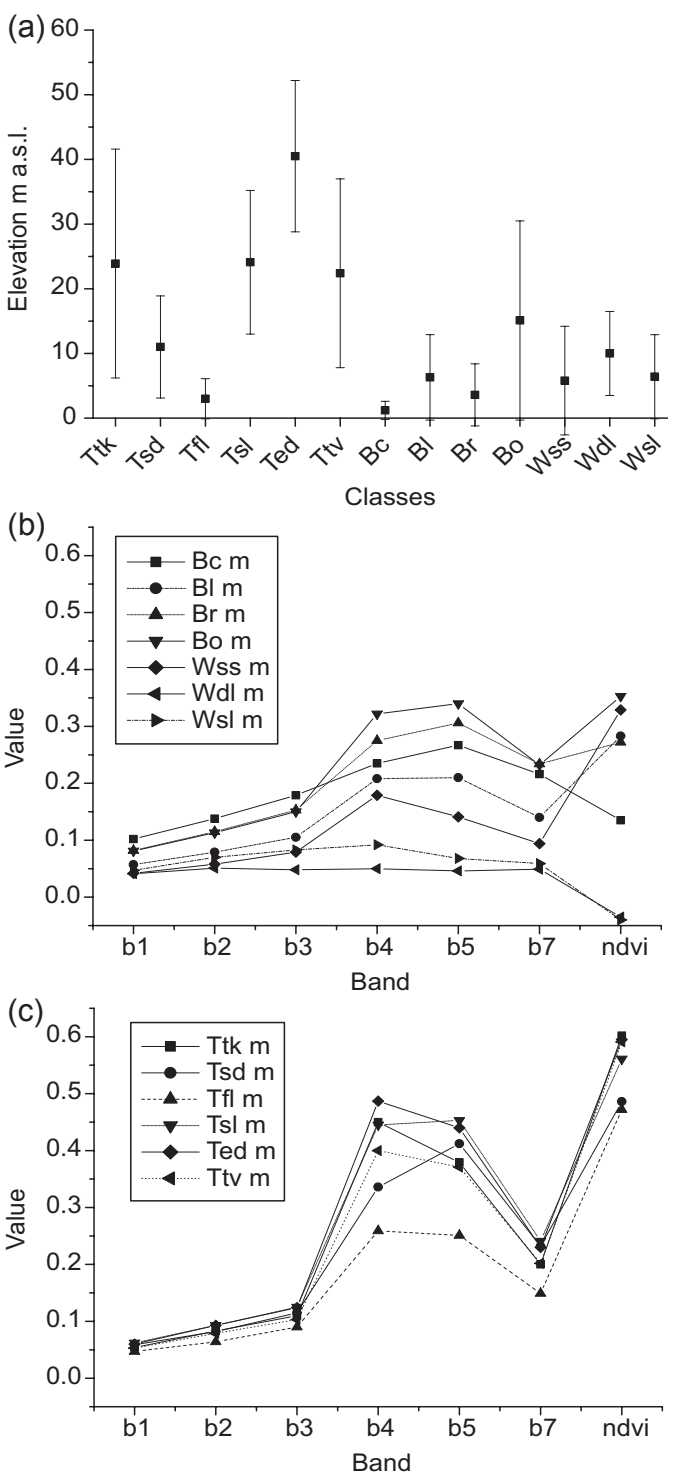

Fig. 7. Mean elevation and spectral characteristics for each class: (a) mean elevation and standard deviation for each class; (b) mean reflectance and NDVI for barren and water classes; (c) mean reflectance and NDVI for vegetated tundra classes).

related fluxes of sediment and organic matter to the Arctic Ocean. It is moreover a foundation for a more precise quantification of present day energy and matter fluxes, as well as for the detection of future changes under changing climatic conditions in the Arctic. Hence, it is necessary to develop efficient mapping techniques based on current datasets with large coverage and high detail. Our 
method using Landsat-7 ETM+ remote sensing data with $30 \mathrm{~m}$ spatial resolution and DEM based on available topographical maps is such a technique. It can be easily adapted to other Arctic periglacial regions and delivers new spatial information on the extent and distribution of periglacial terrain, and the intensity of periglacial processes like thermokarst. The results can be used for the comparison of Holocene thermokarst processes on a pan-Arctic scale, for the assessment of coastal dynamics, and for the support of regional palaeo-environmental reconstructions.

Obviously, thermokarst formation and subsidence processes were the dominating factors of landscape dynamics in the coastal plain around Cape Mamontov Klyk during the Holocene. In a similar study using CORONA imagery, Grosse et al. (2005) found that $53.1 \%$ of the Bykovsky Peninsula area (excluding slope areas) in the eastern Laptev Sea was affected by thermokarst. This value is comparable to the value for the Lena-Anabar lowland (48.7\%), when excluding the yedoma uplands (Ted) and the slopes (Tsl). Higher values of thermokarst-affected terrain are reported for a $1572 \mathrm{~km}^{2}$ large study area on the Barrow Peninsula in Alaska, where the area, including drained thermokarst basins and lakes, was quantified at $72 \%$ (Hinkel et al. 2003). Similarly high values can be expected for the YanaIndigirka Lowland, as suggested by preliminary visual inspections of Landsat-7 ETM+ imagery.

The spatial distribution and morphology of thermokarst and thermo-erosion features in the investigation area indicate the self-reinforcing effect of thermokarst formation in ice-rich permafrost and accompanied drainage change. Persistent thermal denudation and slope processes like solifluction or slope wash lead to spatial expansion and coalescence of negative relief structures. The significance of these still active processes is suggested by the extensive areas classified as slopes (Tsl: 29\%). The yedoma surfaces (Ted) are considered to be the remnants of the palaeo-surface of an extended Late Pleistocene accumulation plain in front of the Pronchishchev Ridge. Near the hills in the south, this surface is much less dissected by thermo-erosional valleys, extent thermokarst depressions, and slopes, than close to the coast (Fig. 6). In the southern uplands the discharge is more directional and the terrain is better drained than in the lower coastal region. Extensive subsidence areas have formed near the mouths of large rivers at the coast. Here, the thermo-erosive effect of rivers is combined with the subsidence of thermokarst depressions. These spatial patterns suggest that thermokarst in the region did not develop evenly, but was strongly dependent on the development of the hydrology.

Two types of thermokarst struktures are present in the region: extensive lowlands at the coast, especially at river mouths, and distinct and predominantly north-south oriented depressions on interfluve areas. Depending on the maturity of the depression, the thickness of ice-rich permafrost in the ground, and the supply of meltwater from snow and permafrost thawing, the basins contain various types of lakes (Wdl, Wsl or Wss), and subaerial areas (mainly Tsl, Ttk, Ttv and Tfl). Whereas the first thermokarst structure type often is dominated by shallow lakes (Wsl and Wss), the second type contains large north-south oriented lakes (mostly Wdl).

In the first type, various features occur, like active and inactive river channels, truncated and coalesced thermokarst depressions, lakes, lagoons and floodplain-like areas. The lakes are generally shallow, and smaller lakes are often overgrown with vegetation. In basins with shallow or no lakes, ice-rich permafrost is at least partially destroyed. A few basins in the eastern study area show signs of refreezing taliks, indicated by the presence of pingos.

In the second type, the deep lakes are an indicator for the presence of thick ice-rich permafrost, very deep thermokarst, and probably deep talik formation. The bathymetries of three deep lakes in the study region, one situated $14.5 \mathrm{~km}$ and the other two $22 \mathrm{~km}$ away from the coast, were measured by Bolshiyanov \& Makarov (2004). The observed maximum water depths for the central lake basins were $20.5 \mathrm{~m}, 27.0 \mathrm{~m}$ and $29.0 \mathrm{~m}$. When compared to modern lake levels $(19.6 \mathrm{~m}$, $19.9 \mathrm{~m}$ and $18.7 \mathrm{~m}$ a.s.1., respectively), it is clear that the bottoms of all three lakes are situated well below the modern sea level. Two of the lakes are situated only 1.5 to $2 \mathrm{~km}$ north of the Pronchishchev Ridge, indicating the presence of thick ice-rich sediments even close to the hills. These lakes prove the significance of deep thermokarst depressions for the Holocene coastal dynamics as described by Romanovskii et al. (2000, 2004). Thus, the spatial distribution of thermokarst depressions and thermo-erosional valleys strongly influences the pattern of coastal retreat by lagoon formation and sea ingression. The intensive thermokarst processes probably accelerated 
the rapid Holocene coastal retreat in this region.

Our classification refines existing low-resolution coastal and hinterland classifications for this region (Drozdov et al. 2005). This refinement is necessary for the detailed modelling of coastal dynamics along complex ice-rich permafrost coasts, as is proposed in the Arctic Coastal Dynamics project for this and other sites along the Arctic coast (Rachold et al. 2005). Are (1999) estimated coastal retreat rates and sediment supply to the Laptev Sea based on low-resolution shore face data and simplified cryolithological assumptions for a $85 \mathrm{~km}$ long stretch of the coast in the study region. He calculated a mean retreat rate of $2 \mathrm{~m}^{*} \mathrm{y}^{-1}$ and a total sediment yield of 3.4 $M t^{*} \mathrm{y}^{-1}$. Our detailed classification including hinterland and coast can be used to verify and refine these calculations.

\section{Conclusion}

With our classification approach it is possible to classify a complex periglacial Arctic coastal plain and to quantify terrain affected by permafrost degradation on a large scale and in high resolution. The successful approach was based on a combination of Landsat-7 ETM+ remote sensing data, digital elevation data and ground truth data. Basic spatial analysis was used for the enhancement of the classification. The applied technique allowed the separation and interpretation of 13 surface classes and achieved a good overall accuracy $(79 \%)$. The method, with modifications for local peculiarities, is applicable to other sites in the Arctic.

Thermokarst, thermo-erosion and related slope processes affects $78 \%$ (that is, $1807 \mathrm{~km}^{2}$ ) of the area. This high value clarifies the significance of Holocene thermokarst processes for landscape dynamics in Arctic lowlands and the importance of considering permafrost degradation under current global change scenarios.

Permafrost degradation directly influenced the palaeogeography by changing the palaeohydrology from a regional regime with loosely distributed lateral runoff in a gentle Late Pleistocene accumulation plain far from the coast to a locally organized hydrological system with runoff towards numerous thermokarst depressions, thermo-erosional valleys, and river valleys in a Holocene coastal plain. Terrain types are not evenly distributed in the investigated region, indicating a directed environmental forcing. Permafrost degradation terrain increases from south to north on the northward inclined coastal plain. The non-degraded Late Pleistocene terrain surface of the yedoma uplands is more abundant in the south near the hills.

Acknowledgements.-The field campaign in the coastal region of Cape Mamontov Klyk was part of the research project Process Studies of Permafrost Dynamics in the Laptev Sea, funded by the German Federal Ministry of Education and Research (BMBF project no. 03G0589). In this context we thank the other participants of the field campaign. The first author would also like to thank the German Academic Exchange Service (DAAD) for a grant that enabled a four month research visit to the School of GeoSciences, University of Edinburgh. During this period atmospheric correction methods and first classification approaches were evaluated. Furthermore, thanks are due to Anne Morgenstern for her efforts in digitizing the topographic maps, as well as to HansWolfgang Hubberten and two anonymous referees for helpful comments on the manuscript.

\section{References}

ACIA (Arctic Climate Impact Assessment) 2004: Impacts of a warming Arctic: Arctic Climate Impact Assessment. Cambridge: Cambridge University Press.

Are, F. E. 1999: The role of coastal retreat for sedimentation in the Laptev Sea. In H. Kassens et al. (eds.): Land-ocean systems in the Siberian Arctic: dynamics and history. Pp. 287-295. Berlin: Springer-Verlag.

Bartsch, A., Gude, M., Jonasson, C. \& Scherer, D. 2002: Identification of geomorphic process units in Kärkevagge, northern Sweden, by remote sensing and digital terrain analysis. Geogr. Ann. Ser. A Phys. Geogr. 84, 171-178.

Black, R. F. 1969: Thaw depressions and thaw lakes-a review. Biul. Peryglac. 19, 131-150.

Bolshiyanov, D. \& Makarov, A. 2004: Geomorphologic route along the Urasalakh River. In L. Schirrmeister et al. (eds.): Russian-German Cooperation System Laptev Sea: The Expedition Lena-Anabar 2003. Rep. Polar Mar. Res. 489, 67-74.

Chavez, P. S. 1996: Image-based atmospheric correctionsrevisited and improved. Photogramm. Eng. Remote Sens. 62, 1025-1036.

Czudek, T. \& Demek, J. 1970: Thermokarst in Siberia and its influence on the development of lowland relief. Quat. Res. $1,103-120$.

Drozdov, D. S., Rivkin, F. M., Rachold, V., Ananjeva-Malkova, G. V., Ivanova, N. V., Chehina, I. V., Koreisha, M. M., Korostelev, Y. V. \& Melnikov, E. S. 2005: Electronic atlas of the Russian Arctic coastal zone. Geo-Mar. Lett. DOI: 10.1007/s00367-004-0189-7.

Ermolin, E., De Angelis, H. \& Skvarca, P. 2002: Mapping of permafrost on Vega Island, Antarctic Peninsula, using 
satellite images and aerial photography. Ann. Glaciol. 34, 184-188.

Etzelmüller, B., Ødegård, R. S., Berthling, I. \& Sollid, J. L. 2001: Terrain parameters and remote sensing data in the analysis of permafrost distribution and periglacial processes: principles and examples from southern Norway. Permafrost Periglacial Process. 12, 79-92.

Florinsky, I. V. 1998: Combined analysis of digital terrain models and remotely sensed data in landscape investigations. Prog. Phys. Geogr. 22, 33-60.

French, H. M. 1974: Active thermokarst processes, eastern Banks Island, western Canadian Arctic. Can. J. Earth Sci. 11, 785-794.

French, H. M. 1996: The periglacial environment. Harlow, UK: Longman.

GLOBE Task Team (Hastings, D. A., Dunbar, P. K., Elphingstone, G. M., Bootz, M., Murakami, H., Maruyama, H., Masaharu, H., Holland, P., Payne, J., Bryant, N. A., Logan, T. L., Muller, J.-P., Schreier, G. \& MacDonald, J. S.) (eds.) 1999: The global land one-kilometer base elevation (GLOBE) digital elevation model, version 1.0. Boulder, CO: NOAA, National Geophysical Data Center.

Grosse, G., Schirrmeister, L., Kunitsky, V. V. \& Hubberten, H.-W. 2005: The use of CORONA images in remote sensing of periglacial geomorphology: an illustration from the NE Siberian coast. Permafrost Periglacial Process. 16, $163-172$.

Gude, M., Daut, G., Dietrich, S., Mäusbacher, R., Jonasson, C., Bartsch, A. \& Scherer, D. 2002: Towards an integration of process measurements, archive analysis and modelling in geomorphology - the Kärkevagge experimental site, Abisko area, northern Sweden. Geogr. Ann. Ser. A Phys. Geogr. 84, 205-212.

Hinkel, K. M., Eisner, W. R., Bockheim, J. G., Frederick, E. N., Peterson, K. M. \& Dai, X. 2003: Spatial extent, age, and carbon stocks in drained thaw lake basins on the Barrow Peninsula, Alaska. Arct., Antarct. Alp. Res. 35, 291-300.

Hopkins, D. M. 1949: Thaw lakes and thaw sinks in the Imuruk Lake area, Seward Peninsula. J. Geol. 57, 119-131.

Hutchinson, M. F. 1989: A new procedure for gridding elevation and stream line data with automatic removal of spurious pits. J. Hydrol. 106, 211-232.

Jorgenson, M. T., Racine, C. H., Walters, J. C. \& Osterkamp, T. E. 2001: Permafrost degradation and ecological changes associated with a warming climate in central Alaska. Clim. Change 48, 551-579.

Joria, P. E. \& Jorgenson, J. C. 1996: Comparison of three methods for mapping tundra with Landsat digital data. Photogramm. Eng. Remote Sens. 62, 163-169.

Lantuit, H. \& Pollard, W. H. 2005: Temporal stereophotogrammetric analysis of retrogressive thaw slumps on Herschel Island, Yukon Territory. Nat. Hazards Earth Syst. Sci. 5, 413-423.

Lewkowicz, A. G. \& Duguay, C. R. 1999: Detection of permafrost features using SPOT panchromatic imagery, Fosheim Peninsula, Ellesmere Island, N.W.T. Can. J. Remote Sens. 25, 33-44.

Mackay, J. R. 1963: The Mackenzie Delta area, N.W.T. Geographical Branch Memoir. Ottawa, Dept. of Mines and Technical Surveys.

MacMillan, R. A., Martin, T. C., Earle, T. J. \& McNabb, D. H. 2003: Automated analysis and classification of landforms using high-resolution digital elevation data: applications and issues. Can. J. Remote Sens. 29, 592-606.
Morrissey, L. A., Strong, L. \& Card, D. H. 1986: Mapping permafrost in the boreal forest with thematic mapper satellite data. Photogramm. Eng. Remote Sens. 52, 1513-1520.

Osterkamp, T. E. \& Romanovsky, V. E. 1999: Evidence for warming and thawing of discontinuous permafrost in Alaska. Permafrost Periglacial Process. 10, 17-37.

Pollard, W. H. \& French, H. M. 1980: A first approximation of the volume of ground ice, Richards Island, Pleistocene Mackenzie delta, Northwest Territories, Canada. Can. Geotech. J. 17, 509-516.

Rachold, V., Are, F. E., Atkinson, D. E., Cherkashov, G. \& Solomon, S. M. 2005: Arctic Coastal Dynamics (ACD)an introduction. Geo-Mar. Lett. DOI: 10.1007/s00367-0040187-9.

Rachold, V., Grigoriev, M. N., Are, F. E., Solomon, S., Reimnitz, E., Kassens, H. \& Antonow, M. 2000: Coastal erosion vs riverine sediment discharge in the Arctic Shelf seas. Int. J. Earth Sci. 89, 450-460.

Romanovskii, N. N. 1961: Erozuonno-termokarstovye kotloviny na severe Primorskikh nizmennostei Yakutii i Novosibirskikh Ostrovakh. (Erosion-thermokarst basins in the northern marine plains of Yakutia and the New Siberian Islands.) Merzlotnye Issledovaniya. Sbornik Statey 1, 124144.

Romanovskii, N. N., Hubberten, H.-W., Gavrilov, A. V., Tumskoy, V. E. \& Kholodov, A. L. 2004: Permafrost of the east Siberian Arctic shelf and coastal lowlands. Quat. Sci. Rev. 23, 1359-1369.

Romanovskii, N. N., Hubberten, H.-W., Gavrilov, A. V., Tumskoy, V. E., Tipenko, G. S., Grigoriev, M. N. \& Siegert, C. 2000: Thermokarst and land-ocean interactions, Laptev Sea region, Russia. Permafrost Periglacial Process. 11, 137-152.

Schirrmeister, L., Grigoriev, M. N., Kutzbach, L., Wagner, D. \& Bolshiyanov, D. (eds.) 2004: Russian-German Cooperation System Laptev Sea: The Expedition Lena-Anabar 2003. Rep. Polar Mar. Res. 489.

Schirrmeister, L., Siegert, C., Kuznetsova, T., Kuzmina, S., Andreev, A., Kienast, F., Meyer, H. \& Bobrov, A. 2002: Paleoenvironmental and paleoclimatic records from permafrost deposits in the Arctic region of northern Siberia. Quat. Int. 89, 97-118.

Sellmann, P. V., Brown, J., Lewellen, R. I., McKim, H. L. \& Merry, C. J. 1975: The classification and geomorphic implications of thaw lakes on the Arctic Coastal Plain, Alaska. U.S. Army Cold Reg. Res. Engin. Lab. Res. Rep. 344.

Semiletov, I. P., Pipko, I. I., Pivovarov, N. Y., Popov, V. V., Zimov, S. A., Voropaev, Y. V. \& Daviodov, S. P. 1996: Atmospheric carbon emission from north Asian lakes: a factor of global significance. Atmos. Environ. 30, 16571671.

Smith, L. C., MacDonald, G. M., Velichko, A. A., Beilman, D. W., Borisova, O. K., Frey, K. E., Kremenetski, K. V. \& Sheng, Y. 2004: Siberian peatlands - a net carbon sink and global methane source since the Early Holocene. Science 303, 353-356.

Soloviev, P. A. 1973: Thermokarst phenomena and landforms due to frostheaving in central Yakutia. Biul. Peryglac. 23, $135-155$.

Treshnikov, A. F. (ed.) 1985: Atlas Arktiki. (Atlas of the Arctic.) Moscow: National Commission of Hydro-Meteorology and Environmental Protection, Major Dept. of Geodesy and Cartography.

van Everdingen, R. (ed.) 1998 (revised May 2005): Multi- 
language glossary of permafrost and related ground-ice terms. Boulder, CO: National Snow and Ice Data Center/ World Data Center for Glaciology. Online at http://nsidc. org/fgdc/glossary/index.html.

Virtanen, T., Mikkola, K. \& Nikula, A. 2004: Satellite image based vegetation classification of a large area using limited ground reference data: a case study in the Usa Basin, northeast European Russia. Polar Res. 23, 51-66.

Walsh, S. J., Butler, D. R. \& Malanson, G. P. 1998: An overview of scale, pattern, process relationships in geomorphology: a remote sensing and GIS perspective. Geomorphology $21,183-205$.
Washburn, A. L. 1979: Geocryology: a survey of periglacial processes and environments. London: Edward Arnold.

Wulder, M. A., Franklin, S. E., White, J. C., Cranny, M. M. \& Dechka, J. A. 2004: Inclusion of topographic variables in an unsupervised classification of satellite imagery. Can. J. Remote Sens. 30, 137-149.

Yershov, E. D. 1998: General geocryology. Studies in polar research. Cambridge: Cambridge University Press.

Zhang, T., Barry, R. G., Knowles, K., Heginbottom, J. A. \& Brown, J. 1999: Statistics and characteristics of permafrost and ground-ice distribution in the Northern Hemisphere. Polar Geogr. 23, 132-154. 
